\title{
Pengembangan Soal Matematika Realistik Berdasarkan KERANGKa TEORI Program For InTERnATIONAL STUDENTS ASSESMENT
}

\author{
Navel Oktaviandy Mangelep1 ${ }^{*}$, Derel Filandy Kaunang² \\ 1Program Studi Pendidikan Matematika, FMIPA, Universitas Negeri Manado \\ Jl Tondano, Koya, Tondano Selatan, Manado, Sulawesi Utara, 95618, Indonesia \\ navelmangelep@unima.ac.id \\ ${ }^{2}$ Program Studi Pendidikan Matematika, FMIPA, Universitas Negeri Manado \\ Jl Tondano, Koya, Tondano Selatan, Manado, Sulawesi Utara, 95618, Indonesia
}

Artikel diterima: 5 Agustus 2018, direvisi: 23 September 2018, diterbitkan: 30 September 2018

\begin{abstract}
Abstrak
Penelitian ini bertujuan untuk mengembangkan soal matematika realistik berdasarkan kerangka teori PISA yang valid, praktis, dan efektif. Metode yang digunakan dalam penelitian ini adalah metode penelitian pengembangan dengan tipe penelitian formatif yang meliputi tahap preliminary (analisis dan pendesainan) serta tahap prototyping (evaluasi formatif). Teknik pengumpulan data berupa dokumentasi, walk through, tes, observasi, dan wawancara. Sedangkan teknik analisis data yang digunakan adalah analisis data deskriptif kualitatif. Kevalidan dipenuhi berdasarkan validasi pakar secara kualitatif dari aspek konten, konstruk, dan bahasa. Kriteria praktis dipenuhi apabila memenuhi dua hal yaitu; (1) para pakar menyatakan bahwa apa yang dikembangakan dapat diterapkan, dan (2) kenyataan menunjukkan bahwa apa yang dikembangkan tersebut dapat diterapkan. Hasil yang diperoleh adalah telah dihasilkan prototipe soal matematika realistik berdasarkan kerangka teori PISA yang valid dan praktis dan efektif. Selain itu, hasil tes menunjukkan bahwa kemampuan literasi matematika siswa kelas IX di SMP Negeri 3 Tondano masih tergolong rendah dengan rata-rata nilai 19,6.

Kata Kunci: soal, matematika, realistik, PISA. Literasi matematika
\end{abstract}

\begin{abstract}
This study aims to develop valid, practical and effective realistic mathematics problem based on PISA theoretical framework. The method is a developmental research with formative research type which includes the preliminary stage (analysis and design) and the prototyping stage (formative evaluation). Data collection techniques in the form of documentation, walk through, tests, observations, and interviews. While the data analysis technique used is qualitative descriptive data analysis. Validity is fulfilled based on qualitative expert validation from aspects of content, constructs, and language. Practical criteria are fulfilled when fulfilling two things, namely; (1) the experts state that what is developed can be applied, and (2) the fact shows that what is developed can be applied. The results obtained is a realistic mathematical problem prototype based on the PISA theoretical framework that is valid, practical, and effective. In addition, the test results show that the mathematics literacy skills of grade IX students at SMP Negeri 3 Tondano are still relatively low with an average score of 19.6.

Keyword: problem, mathematics, realistic, PISA. Mathematical literacy.
\end{abstract}




\section{Pendahuluan}

Matematika memiliki peran yang sangat penting dalam segala aspek kehidupan terutama dalam bidang teknologi. Harahap (2013) pada penelitiannya menyimpulkan bahwa kemajuan sains dan teknologi yang begitu pesat saat ini tidak lepas dari peranan perkembangan matematika. Sehingga bisa dikatakan landasan utama perkembangan sains dan teknologi adalah matematika. Oleh karena itu, penguasaan matematika menjadi suatu keharusan dalam era persaingan global.

Salah satu program yang menjadi acuan dalam mengukur pencapaian penguasaan matematika di dunia internasional adalah Program for International Students Assessment (PISA). PISA adalah studi internasional dalam mengukur kemampuan literasi matematika, membaca, dan sains pada anak berusia 15 tahun di hampir 70 negera di dunia (OECD, 2010). Khusus pada PISA Matematika, kemampuan yang diukur adalah kemampuan siswa dalam mengidentifikasi, memformulasikan, dan memahami berbagai fakta, prinsip, dan formulasi dalam matematika untuk digunakan dalam memprediksi, mengkomunikasi, dan merefleksi berbagai fenomena dalam kehidupan sehari-hari

Indonesia telah berpartisipasi sebanyak 6 kali dalam PISA, namun prestasi siswa masil belum menunjukkan hasil yang memuaskan karena selalu berada pada peringkat bawah. Hasil terbaru pada PISA

2015 Indonesia berada pada peringkat 62 dari 71 negara peserta (Mangelep, 2015).

Dari hasil PISA tersebut didapatkan data bahwa dalam kurun waktu 2003-2009, $80 \%$ siswa Indonesia hanya mampu mencapai di bawah level 2 dari 6 level soal yang diujikan (Kemdikbud, 2012). Lebih khusus pada PISA 2009, 99\% siswa hanya mampu menyelesaikan soal pada level 1 , 2, dan 3, sedangkan hanya $0,1 \%$ siswa yang mampu menyelesaiakan soal pada level 5 dan 6 (Stacey, 2010).

Salah satu faktor penyebab permasalahan di atas adalah siswa hanya terbiasa menyelesaikan soal-soal tradisional yang menitikberatkan pada penyelesaian prosedur baku. Abstrak, dan tidak terkait dengan kehidupan sehari-hari siswa. Sehingga soal-soal yang membutuhkan penalaran matematis seperti soal PISA akan menjadi sukar untuk diselesaikan oleh siswa-siswa Indonesia. Aniisah (2011) menambahkan bahwa kurangnya soal-soal matematika realistik yang didesain khusus sesuai dengan potensi dan karakter siswa serta menggunakan konteks yang relevan juga menambah faktor ketidakberhasilan Indonesia dalam PISA.

Pengembangan soal matematika realistik yang mengacu pada standar PISA bisa dijadikan alternatif penyelesaian masalah di atas. Hal ini dikarenakan soal model PISA menggunakan pendekatan literasi yang inovatif dan berorientasi ke masa depan (OECD, 2012). Selain itu, berdasarkan penelitian-penelitian sebelumnya tentang PISA seperti 
Mangelep (2012) yang mengembangkan soal matematika pada kompetensi proses koneksi dan refleksi PISA, Evi (2012) yang mengembangkan soal matematika model PISA pada konten uncertainty untuk mengukur kemampuan pemecahan masalah matematika siswa sekolah menengah pertama, Ahyan (2012) yang mengembangkan soal model PISA pada konten change and relationship untuk mengetahui kemampuan penalaran matematis siswa SMP, menunjukkan bahwa soal matematika model PISA memiliki efek potensial (efektif) dalam meningkatkan prestasi belajar matematika siswa.

Selain itu, tes PISA dimaksudkan juga untuk melihat kemampuan siswa menggunakan matematika dalam memecahkan masalah-masalah dalam kehidupan sehari-hari (Marpaung \& Julie,2010). Hal ini sejalan dengan soal matematika realistik yang digunakan dalam pembelajaran PMRI/RME. Dimana dalam PMRI, pembelajaran selalu dimulai dengan menyajikan masalah kontektual/realistik yang dekat dengan siswa.

Berdasarkan hal tersebut, maka perlu dikembangkan soal matematika realistik berdasarkan kerangka teori program for international student assessment.

\section{Metode}

Penelitian ini menggunakan metode penelitian pengembangan dengan tipe penelitian formatif. Penelitian ini terdiri dari tahap preliminary yakni analisis dan pendesainan, serta tahap prototyping yakni tahap evaluasi formatif (Mangelep, 2017).

Penelitian ini dilaksanakan semester genap tahun pelajaran 2016/2017 dengan subjek penelitian yaitu siswa SMP Negeri 3 Tondano Kelas VIII.

Teknik pengumpulan data pada penelitian ini antara lain dokumentasi, walk through, tes, observasi, dan wawancara. Sedangkan teknik analisis data menggunakan analisis dokumen, analisis walk through, analisis tes, serta analisis observasi dan wawancara.

\section{Hasil dan Pembahasan}

\section{A. Tahap Analisis}

Tahap analisis terdiri dari 3 tahapan, yakni analisis siswa, analisis kurikulum, dan analisis soal PISA.

Analisis kemampuan siswa dilakukan pada kelas VIII SMP Negeri 3 Tondano yang menjadi subjek penelitian berdasarkan data dari guru matematika SMP Negeri 3 Tondano pada tahapan oneto-one, didapatkan 3 siswa yang terdiri dari 1 orang siswa yang memiliki kemampuan matematika tinggi, 1 orang siswa yang memiliki kemampuan matematika sedang, dan 1 orang siswa yang memiliki kemampuan matematika rendah. Untuk tahapan small group, didapatkan 6 siswa yang terdiri dari 2 siswa berkemampuan tinggi, 2 orang siswa berkemampuan sedang, dan 2 orang siswa berkemampuan rendah. Pada tahapan field test, berdasarkan analisis kemampuan siswa dipilih siswa kelas IXD

\section{Mosharafa: Jumal Pendidikan Matematika}


yang menjadi subjek penelitian dengan jumlah siswa 18 orang.

Analisis kurikulum dilakukan dengan mengidentifikasi materi pembelajaran matematika SMP sebagai landasan dalam mengembangkan soal PISA. Adapun yang menjadi standar isi pembelajaran adalah aljabar, geometri, bilangan, dan statistika

Dari analisis soal PISA diidentifikasikan karakteristik soal-soal berdasarkan framework PISA dan level kemampuan matematika dalam PISA.

\section{B. Tahap Desain}

Pada tahap ini, peneliti melakukan desain soal matematika standar PISA berdasarkan hasil analisis pada tahap analisis. Pada tahap ini dihasilkan perangkat soal yang didalamnya berisi mengenai:

- Soal-soal berdasarkan standar PISA

- Profil soal

- Jawaban soal

- Pedoman penilaian

Dari hasil tersebut didapatkan prototipe 1 dengan penyebaran konten yang diringkas pada tabel berikut:

Tabel 1.

Deskripsi soal matematika standar PISA yang dikembangkan

\begin{tabular}{|c|c|c|c|c|c|c|c|c|c|c|c|}
\hline \multirow{2}{*}{$\begin{array}{c}\text { Soal } \\
\text { No }\end{array}$} & \multicolumn{4}{|c|}{ Konten } & \multicolumn{4}{|c|}{ Konteks } & \multicolumn{3}{|c|}{ Proses } \\
\hline & $\mathrm{Kn1}$ & $\mathrm{Kn} 2$ & $\mathrm{Kn} 3$ & $\mathrm{Kn} 4$ & $\mathrm{Kt1}$ & $\mathrm{Kt} 2$ & $\mathrm{Kt3}$ & $\mathrm{Kt} 4$ & Pr1 & $\operatorname{Pr} 2$ & $\operatorname{Pr3}$ \\
\hline 1 & $\mathrm{~V}$ & & & & & & $\mathrm{~V}$ & & & & $\mathrm{~V}$ \\
\hline 2 & $\mathrm{~V}$ & & & & & & $\mathrm{~V}$ & & & $\mathrm{~V}$ & \\
\hline 3 & & & & $\mathrm{~V}$ & & $\mathrm{~V}$ & & & & & $\mathrm{~V}$ \\
\hline 4 & & $\mathrm{~V}$ & & & $\mathrm{~V}$ & & & & & $\mathrm{~V}$ & \\
\hline 5 & & & $\mathrm{~V}$ & & & & $\mathrm{~V}$ & & $\mathrm{~V}$ & & \\
\hline 6 & & & V & & & & $\mathrm{V}$ & & V & & \\
\hline 7 & & & & $\mathrm{~V}$ & & & & $\mathrm{~V}$ & & & V \\
\hline 8 & & & $\mathrm{~V}$ & & $\mathrm{~V}$ & & & & $\mathrm{~V}$ & & \\
\hline 9 & & & $\mathrm{~V}$ & & $\mathrm{~V}$ & & & & $\mathrm{~V}$ & & \\
\hline 10 & & & $\mathrm{~V}$ & & $\mathrm{~V}$ & & & & & $\mathrm{~V}$ & \\
\hline
\end{tabular}

Keterangan:

Kn1 :Perubahan dan Hubungan

Kn2 :Ruang dan Bentuk

Kn3 : Konten Kuantitas

Kn4 : Ketidakpastian dan Data

Kt1 : Konteks Pribadi

Kt2 : Konteks Pekerjaan

Kt3 : Konteks Umum

Kt4 : Konteks IImiah

Pr1 : Merumuskan (formulate)

Pr2 : Menerapkan (employ)

Pr3 : Menafsirkan (interpret) 


\section{Tahap Evaluasi Formatif}

\section{Self Evaluation}

Tahap ini dilakukan penilaian terhadap soal yang dikembangkan. Peneliti mengecek kesesuaian hasil desain dengan framework PISA, jawaban, profil soal beserta pedoman penilaian. Hasil penelitian ini adalah prototipe 1 yang divalidasi oleh pakar/ahli dan teman sejawat.

\section{Expert Review}

Tahap ini dilakukan validasi prototipe 1 secara kualitatif oleh beberapa pakar dan teman sejawat untuk memvalidasi prototipe tersebut. Beberapa komentar umum yang diberikan oleh ahli mengenai prototipe 1 diuraikan dalam tabel di bawah ini:

Tabel 2

Komentar Umum Validator Mengenai Prototipe 1

\begin{tabular}{|c|c|}
\hline Validator & Komentar \\
\hline V1 & $\begin{array}{l}\text { Satu persoalan utama mengenai soal adalah soalnya terlalu rumit dan banyak kata-kata. } \\
\text { Tolong untuk mengirim timeline yang baru, sehingga dapat dilihat apa yang bisa saya buat. }\end{array}$ \\
\hline \multirow[t]{4}{*}{ V2 } & $\begin{array}{l}\text { Secara umum, banyak konteks yang menarik yang disajikan dalam prototipe ini. Konteks } \\
\text { juga cukup berimbang dari segi kategorinya. Hanya saja belum ada konteks "Pekerjaan". } \\
\text { Bisa dipertimbangkan untuk mendesain soal dengan tipe ini. Demikian juga dari sisi konten } \\
\text { juga cukup berimbang. Konteks sangat mungkin untuk dikembangkan ke dalam berbagai } \\
\text { macam soal lagi dengan konten PISA yang berbeda-beda. }\end{array}$ \\
\hline & $\begin{array}{l}\text { Perlu ditambahkan soal yang memang benar-benar masuk kategori "Formulate" dimana } \\
\text { siswa sendiri yang menentukan model matematika apa yang harus digunakan, atau dengan } \\
\text { kata lain soal dari konteks nyata yang autentik dengan banyak bentuk representasi } \\
\text { cara/jawaban yang berbeda, strategi pemecahan masalah yang beragam, dan menuntut } \\
\text { penalaran dan argumentasi matematis yang cukup kompleks. }\end{array}$ \\
\hline & $\begin{array}{l}\text { Masalah yang diangkat oleh PISA adalah masalah autentik dalam kehidupan sehari-hari } \\
\text { yang memang perlu diselesaikan. Untuk ini, PISA menggunakan jenis konteks yang bukan } \\
\text { kamuflase, konteks yang diperlukan untuk melakukan matematisasi/pemodelan, dan } \\
\text { konteks yang digunakan untuk menyelesaikan masalah sehari-hari sehingga konteks tidak } \\
\text { lepas begitu saja dengan konten matematika yang diujikan }\end{array}$ \\
\hline & $\begin{array}{l}\text { Informasi umum yang ada di bawah judul konteks sebaiknya dibuat dalam } \\
\text { kalimat/informasi yang seefektif mungkin agar mudah terbaca oleh siswa. Akan } \\
\text { lebih baik jika hanya informasi yang relevan saja yang disajikan untuk digunakan dalam } \\
\text { penyelesaian soal-soal yang ada di dalam unit konteks itu. }\end{array}$ \\
\hline V3 & Lengkapi profil soal mengenai materi apa yang berhubungan dengan soal tersebut \\
\hline
\end{tabular}


3. Tahap One-to-One

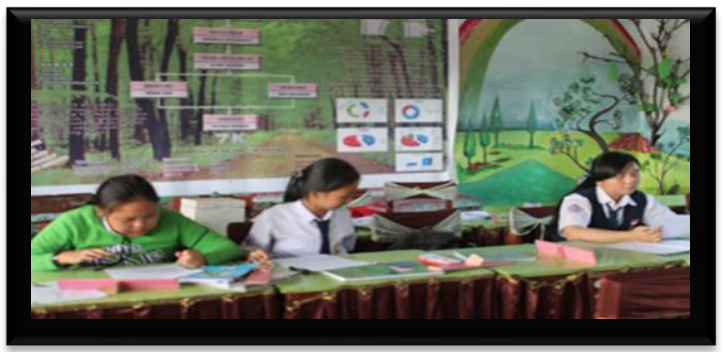

Gambar 1. Tahap One-to-one

Tahap one-to-one dilaksanakan pada tanggal 15 Maret 2017 dengan mengujikan prototipe 1 pada 3 orang siswa kelas VIII di SMP Negeri 3 Tondano yang berkemampuan tinggi, sedang, dan rendah. Adapun siswa yang dipilih pada tahap one-to-one adalah JM, MS, TK. Pelaksanaan tahap ini difokuskan pada kepraktisan dan kejelasan soal yang digunakan, beserta ketertarikan siswa pada soal-soal yang diberikan. Fokus ini berbeda dengan tahap Small Group dikarenakan tahap ini merupakan uji kesesuaian antara pendapat expert dan kenyataan di lapangan. Sehingga dilihat kepraktisan prototipe yang dihasilkan.

Beberapa komentar/saran yang diberikan pada tahap ini dirangkum pada table berikut:

Tabel 3.

Komentar dan Saran Siswa Pada Tahap One-To-One

\begin{tabular}{|c|c|c|c|}
\hline Komentar / Saran & S1 & S2 & S3 \\
\hline - Kata - kata pada nomor 1 diperjelas seperti kata "konstan" & $\mathrm{V}$ & & \\
\hline - Soal - soalnya sangat menarik & $\mathrm{V}$ & $\mathrm{V}$ & $\mathrm{V}$ \\
\hline - Soal - soalnya tidak membosankan, anti mainstream & $\mathrm{V}$ & & \\
\hline $\begin{array}{l}\text { - Soal-soalnya berhubungan dengan kehidupan sehari - hari sehingga menuntut untuk } \\
\text { berpikir logis dan kritis }\end{array}$ & $\mathrm{V}$ & $\mathrm{V}$ & $\mathrm{V}$ \\
\hline - Soal nomor 5 agak susah karena penjelasan yang berbelit-belit & & $\mathrm{V}$ & $\mathrm{V}$ \\
\hline - Gambar pada nomor 3 kurang jelas & $\mathrm{V}$ & & \\
\hline - Nomor 1 dan 2 cukup sulit, yang lain cukup mudah & $\mathrm{V}$ & & \\
\hline $\begin{array}{l}\text { - Alangkah baiknya jika soal tentang "tingkat kepadatan tulang" dibuat dalam bentuk } \\
\text { benar/salah }\end{array}$ & $\mathrm{V}$ & & \\
\hline $\begin{array}{l}\text { - Sebagian besar soal yang diberikan cukup sulit karena contoh soal-soal seperti ini } \\
\text { jarang diberikan }\end{array}$ & & & $\mathrm{V}$ \\
\hline $\begin{array}{l}\text { - Soal-soalnya menambah wawasan dalam berlalu lintas (Soal nomor 1) beserta } \\
\text { pengetahuan tentang kebutuhan kalori }\end{array}$ & $\mathrm{V}$ & & \\
\hline - Soal-soal yang diberikan sebagian besar dapat dimengerti & $\mathrm{V}$ & $\sqrt{ }$ & $\mathrm{V}$ \\
\hline \multicolumn{4}{|l|}{ Keterangan: } \\
\hline : Siswa dengan kemampuan matematika yang tinggi & & & \\
\hline : Siswa dengan kemampuan matematika yang sedang & & & \\
\hline : Siswa dengan kemampuan matematika yang rendah & & & \\
\hline
\end{tabular}




\section{Tahap Small Group}

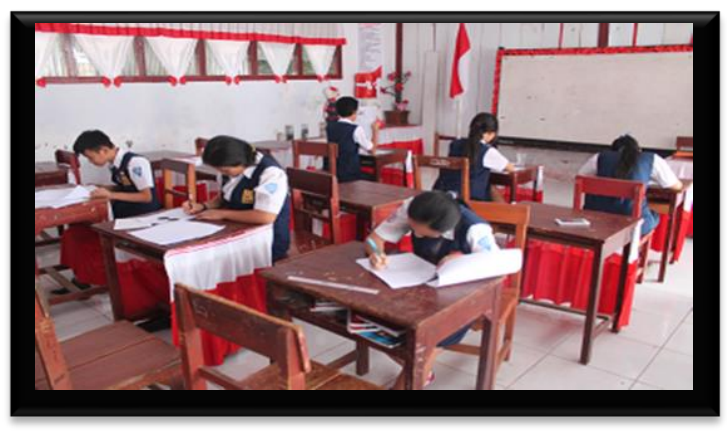

Gambar 2. Tahap Small Group

Tahap uji kelompok kecil (small group) dilaksanakan pada tanggal 29 Maret 2017 di SMP Negeri 3 Tondano kelas VIIIE. Tahap ini diikuti oleh 6 orang siswa yang memiliki kemampuan beragam, yakni 2 orang berkemampuan tinggi, 2 orang berkemampuan sedang, dan 2 orang berkemampuan rendah. Pada tahap ini siswa diminta untuk menjawab prototipe 2 yang telah direvisi sebanyak 9 soal pada tahap sebelumnya selama 60 menit, kemudian diminta untuk memberikan komentar dan saran terhadap prototipe 2

Pada tahap ini dilihat tingkat keefektifan soal yang diberikan, apakah soal hasil revisi yang diberikan memberikan pengaruh kepada tingkat pemahaman siswa atau justru sebaliknya. Hal ini berbeda dengan tahap one-to-one yang hanya fokus pada keterbacaan dan keterlaksanaan prototipe yang digunakan. Berikut adalah rekapitulasi hasil tes pada tahap small group.

Tabel 4.

Skor perolehan siswa pada tahap Small Group

\begin{tabular}{|ccccccccccc|}
\hline No & KS & \multicolumn{10}{c|}{ Skor yang Diperoleh } \\
\cline { 2 - 12 } & & A1 & A2 & A3 & B1 & B2 & C1 & D1 & E1 & E2 \\
\hline 1 & S1 & 4 & 0 & 4 & 4 & 0 & 2 & 2 & 4 & 4 \\
\hline 2 & S2 & 2 & 4 & 0 & 0 & 0 & 2 & 4 & 2 & 4 \\
\hline 3 & S3 & 4 & 0 & 2 & 0 & 2 & 2 & 2 & 4 & 4 \\
\hline 4 & S4 & 4 & 4 & 2 & 0 & 2 & 2 & 2 & 2 & 4 \\
\hline 5 & S5 & 0 & 2 & 2 & 0 & 0 & 2 & 2 & 2 & 2 \\
\hline 6 & S6 & 0 & 2 & 2 & 0 & 0 & 2 & 4 & 0 & 2 \\
\hline
\end{tabular}

Terlihat dari hasil jawaban siswa, beberapa mendapatkan skor 0 bukan karena tidak menjawab, namun beberapa kekeliruan dalam menyelesaikan soal yang ada, bahkan beberapa siswa mampu mengidentifikasi nilai variabel yang diketahui pada soal kecepatan unit 2, namun beberapa kesalahan dalam memanipulasi aljabar sehingga mendapatkan hasil yang keliru.
Berdasarkan hal ini, dilakukan revisi pada lembar penilaian soal dengan menambahkan partial credit pada pedoman penilaian dan menambahkan opsi jawaban yang tepat pada kategori Full Credit karena ada beberapa jawaban yang menggunakan konsep yang berbeda dalam menyelesaikan soal. Partial credit dan Full Credit dibutuhkan karena soal yang didesain tidak hanya memiliki 1 jalan 
penyelesaian, sehingga memungkinkan siswa untuk bernalar dalam menemukan jalan penyelesaian yang singkat dan tepat. Seperti siswa S2 yang menyelesaikan soal kecepatan unit 2, S2 tidak mensubstitusi nilai variabel, namun menggunakan konsep perbandingan berbalik nilai untuk mendapatkan hasil. Soal yang menggunakan konteks Tingkat Kepuasan Pelanggan PDAM pada dasarnya menurut siswa dipahami, namun karena ketidaktahuan dalam menggunakan konsep persentase sehingga siswa gagal dalam menjawab soal tersebut.

\section{Tahap Field Test}

Pada tahap ini, hasil pengembangan soal prototipe 3 diujikan pada subjek penelitian field test, yakni siswa SMP Negeri 3 Tondano kelas IX-D sebanyak 18 orang. Penelitian tahap ini dilaksanakan pada tanggal 30 Maret 2017 selama 1 jam. Hasil jawaban siswa diambil sebagai sumber data untuk melihat kemampuan literasi siswa kelas IX di SMP Negeri 3 Tondano.

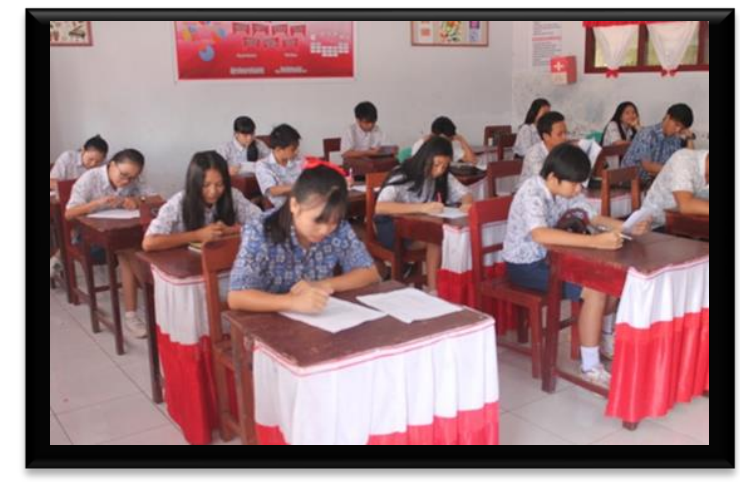

Gambar 3. Tahap Pelaksanaan Field Test di Kelas IXD SMP Negeri 3 Tondano.
Pada tahap ini juga, peneliti bertindak sebagai observer yang mengamati kesulitan-kesulitan yang dialami oleh siswa selama pelaksanaan tes. Tes berlangsung selama 60 menit. Skor yang diperoleh dikelompokkan dalam tabel berikut:

Tabel 5.

Distribusi hasil tes pada tahap Uji Lapangan (Field Test)

\begin{tabular}{|cccc|}
\hline Interval & Frekuensi & Persentase & Kategori \\
\hline$\geq 75$ & 0 & 0 & Sangat Baik \\
\hline $50 \leq x<75$ & 0 & 0 & Baik \\
\hline $25 \leq x<50$ & 6 & 33,33 & Cukup \\
\hline $0 \leq x<25$ & 12 & 66,67 & Kurang \\
\hline Jumlah & 18 & 100 & \\
\hline Nilai Rata -Rata & 19,6 & Kurang \\
\hline
\end{tabular}

Berdasarkan hasil pengembangan maka dihasilkan seperangkat soal matematika berdasarkan standar PISA yang valid dan praktis yang dipenuhi berdasarkan validasi secara kualitatif oleh ahli. Hal ini dapat ditunjukkan berdasarkan hasil penilaian dan komentar validator, bahwa semua pertanyaan dan topik, dan struktur secara umum beserta jawaban atau respon merupakan permulaan yang sangat baik dan juga secara umum banyak konteks yang menarik yang disajikan dalam prototipe ini. Konteks juga cukup berimbang dari segi kategorinya, dan konteks sangat mungkin untuk dikembangkan ke dalam berbagai macam soal lagi dengan konten PISA yang berbeda-beda. Perangkat soal ini dinyatakan oleh ahli PISA, yakni Dave Tout bahwa soal-soal ini relevan untuk anakanak Indonesia. 
Kepraktisan juga selain dinyatakan oleh ahli, dilihat dari hasil tes dan komentar siswa pada tahap one-to-one dan small group, dimana sebagian besar siswa dapat mengerjakan soal-soal dengan baik, siswa dapat mengaktifkan kemampuan matematika mereka dan menggunakan strategi dalam mengerjakan soal, dan soalsoal yang disajikan dapat dipahami oleh siswa. Pada tahap wawancara dalam small group, semua siswa mengakui bahwa soalsoal yang disajikan pada umumnya sangat menarik, dan berhubungan dengan kehidupan sehari-hari serta menambah wawasan siswa, terutama mengenai kebutuhan kalori pada soal unit Angka Metabolisme Basal dan juga mengenai batas kecepatan kendaraan.

Selanjutnya pada tahap small group, hasil tes siswa menunjukkan bahwa soalsoal yang dikembangkan memenuhi syarat efektif, dimana siswa mampu menggunakan kemampuan matematika yang dimiliki dalam mengerjakan soal.

Berdasarkan pembahasan hasil tes siswa tahap field test pada soal tiap-tiap nomor dan hasil tes siswa pada tahap small group, terlihat bahwa soal matematika yang dikembangkan dapat menggali potensi matematika siswa, dimana siswa dituntut untuk menggunakan kemampuan matematika yang diketahui secara optimal dalam menyelesaikan permasalahan yang berhubungan dengan kehidupan seharihari. Sebagian siswa mampu menyelesaikan soal yang diberikan, namun ada juga siswa yang kurang mampu Mosharafa: Jurnal Pendidikan Matematika Volume 7, Nomor 3, September 2018 Copyright @ 2018 Mosharafa: Jurnal Pendidikan Matematika menyelesaikan soal. Berdasarkan hasil dari suvei yang diisi oleh siswa, 14 dari 18 orang berpendapat bahwa soal-soal yang disajikan pada umumnya sangat menarik. Seluruh siswa yang mengikuti tahap field test mengaku bahwa soal-soal seperti ini jarang sekali disajikan dalam pembelajaran, sehingga siswa kurang mampu dalam menghubungkan pengetahuan yang telah dipelajari di sekolah dengan soal-soal yang berorientasi pada konteks dunia nyata.

Berdasarkan hasil analisis ini dapat dinyatakan bahwa soal-soal yang dikembangkan memenuhi aspek efektif (memiliki efek potensial dalam menggali kemampuan matematika siswa). Dari 18 orang siswa yang mengikuti tahap field test, tidak ada siswa yang masuk dalam kategori baik maupun sangat baik, 6 orang siswa (33,33 \%) yang masuk pada kategori cukup dan 12 orang $(66,67 \%)$ yang masuk pada kategori kurang. Rata-rata nilai siswa pada tahap ini adalah 19,6 pada skala nilai 0 sampai 100 . Berdasarkan hasil rata-rata maka ditarik kesimpulan bahwa kemampuan literasi matematika kelas IX SMP Negeri 3 Tondano masih sangat rendah.

\section{Penutup}

Kesimpulan sementara yang dapat diperoleh dari penelitian ini antara lain: 1) Penelitian ini menghasilkan soal-soal matematika standar PISA sebanyak 9 soal dari berbagi konten dan konteks. Soal yang dikembangkan telah memenuhi kriteria valid. Hal ini ditunjukkan dari penilaian dan 
komentar validator. Selain itu, soal-soal yang dikembangkan memenuhi kriteria praktis, dimana para ahli menyatakan bahwa soal yang dikembangkan dapat diterapkan untuk siswa, dan sesuai dengan kenyataan di lapangan pada pelaksanaan tahap one-to-one dan small group, dimana siswa mampu memahami perangkat soal dengan baik. Soal-soal yang dikembangkan juga memenuhi kriteria efektif yang dilihat dari jawaban siswa dimana setiap siswa menggunakan kemampuan matematika yang dimiliki untuk mengerjakan soal-soal pada tahap small group dan field test. Soal-soal yang dikembangkan pada tahap small group dan field test dikatakan menarik dan sangat berhubungan dengan kehidupan sehari-hari; dan 2) Hasil tes pada tahap field test menunjukkan bahwa kemampuan literasi matematika siswa kelas IX di SMP Negeri 3 Tondano masih tergolong rendah dengan rata-rata nilai 19,6 .

Berdasarkan hasil sementara yang didapatkan, maka dapat disarankan hal-hal sebagai berikut: 1) Bagi peneliti yang ingin meneliti dengan penelitian sejenis, unit soal yang telah dikembangkan dalam penelitian ini masih sangat mungkin untuk dikembangkan dengan konten dan konteks beserta format soal yang berbeda; dan 2) Hasil penelitian ini dapat digunakan sebagai masukan dan saran bagi peneliti lain untuk penelitian tentang pengembangan soal matematika standar PISA

\section{UCAPAN TERIMA KASIH}

Diucapkan terima kasih kepada Rektor Universitas Negeri Manado melalui Lembaga Penelitian UNIMA yang telah mendanai penelitian ini lewat Skim Penelitian Kreativitas dengan anggaran PNBP Unima tahun 2017.

\section{Daftar Pustaka}

Ahyan, S. (2012). Pengambangan Soal Model PISA Pada Konten Change and Relationship Untuk Mengetahui Kemampuan Model PISA Pada Konten Change and Relationship Untuk Mengetahui Kemampuan Penalaran Matematis Siswa Sekolah Menengah Pertama. Tesis. Palembang: FKIP UNSRI

Annisah. (2011). Pengembangan Soal Matematika Model PISA pada Konten Quantity Untuk Mengukur Kemampuan Penelaran Matematis Siswa Sekolah Menengah Pertama. Tesis. Palembang: FKIP UNSRI

Harahap, T. H. (2013). Penerapan Contextual Teaching and Learning Untuk Meningkatkan Kemampuan Koneksi dan Representasi Matematika Siswa Kelas VII SMP Nurhasanah Medan Tahun Pelajaran 2012/2013. Jurnal EduTech, Maret 2015, Volume 1.

Kemdikbud. (2011). Survey International PISA. Diakses November 29, 2016 melalui

http://litbang.kemdikbud.go.id/index. php/survei-intenational-pisa// 
Kemdikbud. (2012). Dokumen Kurikulum

2013. Jakarta: Kemdikbud

Mangelep, N. O. (2013). Pengembangan

Soal Matematika Pada Kompetensi

Proses Koneksi dan Refleksi PISA.

Jurnal Edukasi Matematika, Juni 2013,

Volume 4.

Mangelep, N. O. (2014). Implementasi

Workshop Pembelajaran Bangun

Datar Dengan Pendekatan PMRI Bagi

Guru Sekolah Dasar. Engineering and

Education (E2J), 2(2).

Mangelep, N. O. (2015). Pengembangan

Soal Pemecahan Masalah Dengan

Strategi Finding a Pattern. Konferensi

Nasional Pendidikan Matematika - VI, (KNPM6, Prosiding), 104-112.

Mangelep, N. O. (2017). Pengembangan

Perangkat Pembelajaran Matematika

Pada Pokok Bahasan Lingkaran

Menggunakan Pendekatan PMRI Dan

Aplikasi

GEOGEBRA. Jurnal

Mosharafa, 6(2), 193-200.

Mangelep, N. O. (2017). Pengembangan

Website Pembelajaran Matematika

Realistik Untuk Siswa Sekolah Menengah Pertama. Jurnal

Mosharafa, 6(3), 431-440

OECD. (2010). PISA 2009 Result: What

Students Know and Can Do. STUDENT

PERFORMANCE IN READING,

MATHEMATICS, AND SCIENCE.

(Volume 1). Paris: OECD

OECD. (2010). PISA 2012 Mathematical

Framework. Paris: OECD

Stacey, K. (2010). The PISA View of

Mathematical Literacy in Indonesia.
Journal on Mathematics Education (IndoMS-JME). Juli 2011, Volume 2

Yosita, E. (2012). Pengembangan Soal Matematika Model Pisa Pada Konten Uncertainty Untuk Mengukur Kemampuan Pemecahan Masalah Matematika Siswa Sekolah Menengah Pertama. Tesis. Palembang: FKIP Unsri

\section{Riwayat Hidup PENULIS}

\section{Navel Oktaviandy Mangelep, S.Pd, M.Pd.}

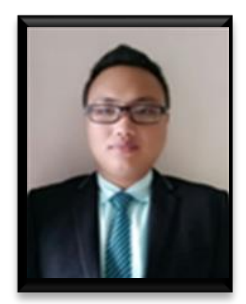

Lahir di Biak Nunfor, tanggal 30 oktober 1988. Staf pengajar di Program Studi Pendidikan Matematika FMIPA Universitas Negeri Manado. Studi S1 Pendidikan Matematika di Universitas Negeri Manado, lulus tahun 2010; S2 Pendidikan Matematika di Universitas Sriwijaya Palembang, lulus tahun 2013.

\section{Derel Filandy Kaunang, S.Pd., M.Pd.}

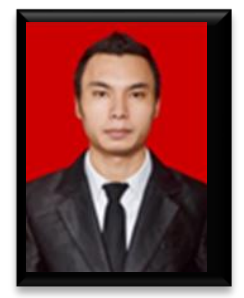

Lahir di Tomohon, tanggal 26 Januari 1990. Staf pengajar di Program Studi Pendidikan Matematika FMIPA Universitas Negeri Manado. Studi S1 Pendidikan Matematika di Universitas Negeri Manado, lulus tahun 2012; S2 Pendidikan Matematika di Universitas Negeri Surabaya, lulus tahun 2014. 
This page is intentionally left blank 